\title{
DIALOGIC RUPTURES: AN ETHICAL IMPERATIVE
}

\begin{abstract}
Dialogue is promoted as a key strategy to 'solve' the 'problem' of diversity in educational settings. Yet, "[w]hen we select words... We usually take them from other utterances, and mainly from utterances that are kindred to ours in genre, that is in theme, composition or style" (Bakhtin, 1986, p. 87, emphasis in the original). This paper problematizes the complexities of dialogic engagements with foreigner teachers in educational encounters. Bakhtin's treatment of polyphonic dialogic encounters provides an analytical frame for explicating the intertextuality of foreigner teacher engagements as not only temporally and culturally, but also individually volatile. The paper suggests that dialogic encounters are unpredictably complex, alive and never neutral, and that dialogic engagements can be so fraught with fear that verbal or cross cultural engagements with teacher foreigners must be recognized as risky and dangerous, and not always smooth 'solutions' to a 'problem'. A dual Bakhtinian/Kristevan lens expands the analysis to expose the vulnerability of dialogue, through unconscious revelations of teacher subjects that are forever in process. The paper culminates in an argument for the crucial importance of a receptive, attentive ethics of care in dialogic engagements with cultural foreigners in educational relationships, to avoid fearful exposure, lifeless dialogue and silence.
\end{abstract}

When we select words... We usually take them from other utterances, and mainly from utterances that are kindred to ours in genre, that is in theme, composition or style (Bakhtin, 1986, p. 87, emphasis in the original).

\section{Introduction}

Dialogic utterances can both connect, and alienate. In exploring this contradiction, this paper argues for the ethical imperative of rupturing common expectations of smoothness in dialogue, with a particular focus on immigrant teachers' intercultural encounters. The paper examines notions of Mikhail Bakhtin's dialogism in relation to ethical and moral commitments in dialogic engagements with the Other, the foreigner, amongst the social, relational and conceptual messiness and unpredictability that complicates Otherness. Grounded in a concern for teacher foreigners and their teaching and relational encounters, I problematize the common conception of dialogue as a remedy for issues and tensions in intercultural encounters in educational settings. A Bakhtinian dialogic lens is applied to analyse this conception in relation to foreigner teacher Otherness, to urge a shift towards increased openness to the complex nature and implications of dialogic engagements. Through the analysis, the paper turns to tensions between seeing dialogue as a bridge, and as a fissure, between supporting communication, and radical silence. Alongside Bakhtin, the analysis draws on the work of Julia Kristeva in support of a critical interrogation of 
intertextuality, and to provide a philosophical grounding of teacher foreignness. The analysis exposes the unpredictably dynamic, organic in dialogic encounters, that are alive, and never neutral, to the point where dialogue can become ruptured, and dialogic engagements can become so fraught with fear and unpredictability that teacher-Other encounters must be approached with utmost care and sensitivity. The paper culminates in an argument for a renewed and meticulous ethics of care and sensitivity towards dialogic engagements with teachers who are cultural foreigners, and their everyday realities in educational settings.

\section{'Solving' the 'problem'}

In the educational discourse dialogue is commonly promoted as a key strategy to 'solve' the 'problem' of diversity in educational settings. Bakhtin's opening quote, however, reflects a tendency to remain within the familiar and known. The point of entry to this paper is a tension, between Bakhtin's pluralist position towards dialogue, as polyphonic and multiple, while at the same time supposing a certain wholeness, as Gurevitch (2000) points out, as “a site for constituting a common, unified world” (p. 243). Through the foreignness of teacher-Others, this paper elevates the sheer complexity, revelatory impact, and consequent inhibitions and fear associated with speech utterances and dialogic engagements. They raise concerns such as that other utterances may be far from kindred, for the foreigner Other, and that maybe neither genre, theme, composition or style is familiar, or even accessible. Perhaps, this paper asks, dialogue can result not only in division, rather than unity, but it may even be impossible in any form, due to such overwhelming strangeness and opposition? And maybe dialogue and the wholeness and sociality it is intended to promote expose cracks, rather than remedies or solutions? Bakhtin's insistence on dialogic engagements as unfinalised actualisations, that are "founded on, sustain, perpetuate and proliferate ... the very nature of humanity" (Gurevitch, 2000, p. 244) affirms and helps us to understand the multiple, polyphonic heterogeneity of cross-cultural teacher foreigner relations - and to expose crucial ethical and moral imperatives.

These imperatives arise in various forms. Bakhtin's dialogism, his 'translinguistic' philosophy, is fundamentally based in two ideas, in the use of signs in human thought, and in the importance of utterance in language (Clark \& Holquist, 1984). This dual focus blurs boundaries of the linguistic and the social/relational implications of dialogue, offering insights into complexities that unsettle and disturb known, safe or comfortable practices and methodologies. An analysis of dialogic engagements with foreigner Others raises what Gurevitch (2000) sees as a "dialogical betweenness" (p. 244) where dialogue not only becomes a tool for communication, but for restoring such wider societal notions as freedom and democracy, through critical interrogations of the speech and its sociality. The inherent morality and ethics involved in this view, captured by Erdinast-Vulcan (1997) in her positioning of Bakhtin in an unresolved uncertainty towards ethics and agency, places Bakhtin on the threshold of what can be posited as a dialogic rupture. From this threshold positioning, the subject can be seen as yearning for an ethical grounding, recognized through Bakhtin's notions of multiplicity in heteroglossia, and the unruly, in the carnivalesque. Dialogic engagements become problematic, following Gurevitch, when even such seemingly unregulated notions arise out of particular 
presuppositions, that rest on known 'themes, compositions or styles'.

The ruptures that this analysis provokes, respond to Gurevitch's (2000) positioning of Bakhtinian dialogue as on the one hand refuting monologism to elevate plurality and multiplicity in dialogue, yet at the same time expecting a smooth wholeness. Bakhtin's dialogism thus adds critical insights to the explication of teacher-Other engagements in educational research and practices, as both a remedy for and the cause of cracks and unresolved pluralities, while Kristeva's treatments of foreignness and linguistic theory interplay with Bakhtinian theories to analyse these dialogic ruptures. The combined Bakhtinian/Kristevan argument that ensues draws on Kristeva's elevation of Bakhtin's work in French structuralist circles (Lesic-Thomas, 2005), and acknowledges the "intellectual repackaging" (Lesic-Thomas, 2005, p. 1) that is said to have occurred in this process. Thus the analysis is a dual attempt, to account for the expected and the unexpected intricacies of both this relationship between Bakhtinian and Kristevan scholarship, and between dialogic encounters, and the known and unknown, through an ethics of care in dialogic engagements.

\section{Text: 'A (dialogic) tissue, a woven fabric'}

Fitting with the expectation that dialogue might offer a solution to the multiplicity in cross-cultural encounters, Bakhtin (1981) alerts us to the crucial complexity of dialogue. Always formed through the interplay with the as-yet-unknown in language, he suggests that “[t]he word in language is half someone else's. It becomes 'one's own' only when the speaker populates it with his own intention, his own accent when he appropriates the word, adapting it to his own semantic and expressive intention” (pp. 293-294). Through his notion of dialogic heteroglossia he demonstrates this ambivalence in the recognition that many voices intersect in the formation of the dialogic. Heteroglossia is the "peculiar interaction" (p. xix) of the fixed structure of any text (without which communication cannot exist) with its context, that is, its “ability to contain within it many voices, one's own and other voices” (Allen, 2000, p. 29, emphasis in the original). In this sense, text represents the dialogic in either spoken or written utterances, and reflects, as Barthes (1977) reminds us, the origins of text as "a tissue, a woven fabric" (p. 159). Text therefore can be seen as "not a discreet word or sentence", but "the flow of language within a social context” (White, 2009, p. 301). A complicated web is created, as it both absorbs and responds to other written or verbal text and contexts. The ambivalence of text pertains to the unique heteroglossic relationships enacted through its distinct - but not necessarily distinguishable - symbolic and semiotic dimensions.

From Voloshinov's (1973) perspective, words themselves are multidimensional. This positions text as an ethical encounter with otherness in a number of ways, as it cannot be considered only from one monologic standpoint, but demands attention to the polyphony of influential voices, where meaning arises in the dialogic space between "active, responsive agents" (Gardiner, 1992, p. 15). From this perspective, it does not posit one view against another, or one person, in one space or place, against a research subject, or against one way of understanding an immigrant, foreigner teacher or her colleagues. Similarly, it does not present one view as the truth, one theorist as the reified master, or one way of being as the best way, to the exclusion of any other. It cannot. Rather, it 
requires recognition of the entire complex of theme, meaning and judgment, the verbal or written meanings of the warp and weft, and their woven social realities and wider milieu. Text can be seen as an ethical encounter when viewed through the complicated and ongoing 'rewriting' relationships inherent in a Bakhtinian dialogic lens (de Vocht, 2015; Lesic-Thomas, 2005; White, 2015). In this analysis the notions of dialogism and dialogue represent text in all its forms, as de Vocht (2015) states, accepting the complex "holistic understanding of dialogue as any sense making, semiotic practice, interaction or communication” (p. 320).

\section{Intertextuality}

Dialogic encounters then, are confrontations with contexts and society. They represent an intercourse of elements (histories, stratifications, interpretations and ideological positions) in the time and place in which they are constructed. The ambivalence of textual dialogic weavings supports the argument for an ethical approach to cross-cultural encounters, as utterances are never constructed on the basis of the speaker/author's own thoughts alone, but founded on utterances that already existed, and that will continue to exist in the future: in Bakhtin's terms they are always 'double-voiced'. Drawing on Bakhtin's ideas, Kristeva (1980) picks up on the double-voiced relational junction within text to see it as "a permutation of texts, an intertextuality in the space of a given text" (p. 36). In coining the term intertextuality, to replace the term intersubjectivity (LesicThomas, 2005), Kristeva (1986b) appears to privilege the written text, suggesting that "Bakhtinian dialogism identifies writing as both subjectivity and communication ... as intertextuality” (p. 39). Allen (2000) further affirms this focus, claiming that writing is "not an individual, isolated object but, rather, a compilation of cultural textuality" (p. 36). Multiple, interacting intertextual junctions then can be seen as preserving the uncertainty and ambivalence of text, and, through Bakhtin, of more than written text, in dialogic encounters. The ambivalence of the term itself is reflected in Lesic-Thomas' (2005) description of intertextuality as "one of those extremely useful and yet strangely vague theoretical concepts” (p. 1).

Dialogic engagements in educational relationships represent such junctions in foreigner teachers' personal and cultural intertextualities. They invoke their diverse social permutations through engagements, ideological struggles and discourses, situated in different past, present and future societies, and inserted into the realities of their new educational landscape and setting. The multiple voices implicated in their educational relationships include the histories, and cultural subjectivities of being a foreigner teacher, isolated as the too strange stranger, as well as of confronting foreignness, within themselves, and of others. Dialogue that involves such a profusion of voices further strengthens calls for an ethically and morally complex grounding, following what Noddings (2012) has called an inherent longing, for care and morality. A dialogic ethics and morality of care, as de Vocht (2015) also argues through a Bakhtinian 'moral answerability', depends on developing an attentive, receptive and reciprocal relationship with and amongst these multiple voices.

Such an attentive, receptive stance implicates multiple layers of relationships. In the neoliberal Western educational landscape, they become situated amongst globalized, 
universalized benchmarks, business and policy incentives (Arndt, 2013; Codd, 2008; Duhn, 2010; Peters, 2013), and intricately interwoven with delicate histories of indigenous, minority, cultural and political struggles (see for example Ahmed, 2000; Mohanty, 2003; Ritchie, 2008; Ritchie \& Rau, 2006). Confronting these already often conflicting and at times mutually supportive perspectives releases particular reactions, interpretations, and themes, meanings and judgments amongst Gardiner's (1992) 'active, responsive agents' involved in the context of educational relations. Constructed within and in relation to the discourse in which they arise, such dialogic engagements dynamically intersect with previous and current engagements and situations. They demand an ongoing and developing relationship with language as a "ceaseless flow of becoming" (Bakhtin/Volosinov, 1986, p. 66). It is always dialogic, that is, its "meaning and logic" always depend on "what has previously been said and how [it] will be received by others” (Allen, 2000, p. 19). Foreigner teachers’ often risky journeys from a linguistic no-man's land to a rejuvenated linguistic fervor underlie the ethical importance of an ethics of care, focused on dialogue itself as neither static nor neutral, but alive.

\section{Dialogue comes alive}

Dialogue comes 'alive' through the interplay of its many voices (Clark \& Holquist, 1984). Within the ethical imperative to foreground dialogic relationships, lies a demand, also, for ethical attention to what lies ahead, as, in one sense, intertextual confrontations and reactions to earlier dialogue are already the primitively forming, raw, engagements of the future. From a written, textual perspective, the dynamics of a "dialogue among several writings" (p. 36) alludes to a complex relationship not only between time and place, but also between the writer, the addressee and their place in the cultural milieu, and, further still, with the reader, who rewrites the text as she reads/listens, re-reads and responds to it. Text thus comes differently alive in the rejuvenating freshness of each reading, preceding both its impacts on both present and future engagements and relationships.

Volosinov (1973) points to what Bakhtin calls 'addressivity', suggesting that a speaker/reader's relationship with text and dialogue brings forth a fresh orientation towards the dialogic text and its author. In Bakhtin's (1986) terms this addressivity is not something that passes, rather "the quality of turning to someone, is a constitutive feature of the utterance" and "without it the utterance does not and cannot exist” (p. 99). In this sense it is not only the words, but also the speaker/author, with whom the listener/reader engages, in what for Bakhtin is the distinction between language, and communication (Clark \& Holquist, 1984). Such entanglements play out through much more than written and verbal relationships and communication, as White (2015) emphasises, and are highlighted in the dialogic sociality of foreigner teachers' encounters in their new teaching teams and educational settings. In what follows, immigrant teachers are positioned within a globalized educational milieu, through Kristeva’s (1991) metaphorical foreigner lens. They illustrate the intricacy and intimacy of possible - and impossible - reactions and resistances to symbolic and semiotic structures and nuances in the 'life' of dialogic encounters (Arndt, 2012, 2014).

\section{Foreigner dialogic encounters}


Foreigner teachers can be seen to metaphorically illustrate the actors in 'translinguistic' encounters with language signs, utterances, meanings and implications. Their speech and dialogic engagements are impacted by an educational landscape permeated by local and global boundary crossings, foreignness and policy aspirations for working effectively with difference in educational settings. In this panorama intercultural dialogue is widely promoted as a key supportive strategy by which such aspirations can be achieved (Besley \& Peters, 2012; Ho, Holmes, \& Cooper, 2004; May \& Sleeter, 2010). Placing Kristeva’s (1991) foreigner lens on immigrant teachers as the foreigner substantiates the argument for the ethics of complex Bakhtinian dialogic relationships, and most importantly for recognising the ethical imperative in their rupture.

Examined through Kristeva's (1991) notion of the foreigner, immigrant teachers can be perceived as a nobody from nowhere, where their language mirrors a lack of social identity, status and influence, and can become ensnared in a massive void. Whilst the 'natives' in local teaching teams may appear to listen to them, the foreigners' language can become a form of low-level amusement, rather than being taken seriously. With little effort made or support given, foreigner teachers can become the laughing stock of these 'locals' (Kilito, 1994) and their language can collapse into the peaceful release of silence, what Kristeva calls a void. Alternatively, in attempting to make up for not being heard, the foreigners may instead reveal their utter lack, by misplacing and overexerting their linguistic efforts. Already excluded from the social reality, such excessive efforts can result, for example, in their language becoming overly formal, sophisticated, baroque. Even when they speak the new language grammatically well, the foreigner teachers' exaggerated baroque speech remains on the surface, arising from an internal emptiness, confined by their mother tongue, never freed completely, and stilted at the same time, by their fear of failure.

\section{Secret treasury}

The fear of failure is exacerbated by their struggle with another language and its threat to the foreigner teachers' shifting identity, as they hold their new language as something to protect and hide. When a tide of despondency sweeps over the fullness of their being, locked within their language, for now, at least, it can result again, in their engagements emptying only into silence. Swaying between holding on to their mother tongue, and its familiar patterns of speaking and dialogue, and the new language customs, the foreigner teachers can recognise their own alienation. Lost from the grip of that private, internal connection with home, they often strive to perfect their new style, hoping to fit in - and delighting when they do. Can they, as linguistic/cultural Others, each with their own stories, ever become fully belonging to a language to which others are native, but they are not? Or is there invariably a point of anaesthesia from too much effort in doing so, resulting in a lack of meaning and confusion, of sort of, but not quite, belonging in the new place and language, but now also no longer really belonging in the same local, connected way, to their previous home and language?

As foreigners, their awkwardness does have an exotic charm, however peculiar it feels to these teachers, bringing with it, something of their homeland and history. Once freed from the reins of their mother tongue, the teachers may take the plunge, diving utterly and fearlessly into the foreign new language, daringly capable, using words they never 
used before, audacious, even obscene, as if freshly unleashed from prior inhibitions. Thus freed, they contribute now to assessments and teaching plans, give feedback, and speak up within the team. Alternatively, however, they may fall back into that linguistic noman's-land, in-between making an effort, being more or less understood and accepted for the linguistic differences that surface every time they speak, and the state where there seems to be no point, where no locals even care to understand, and the preferred realm between their two languages once again becomes silence.

\section{Dialogic ruptures}

The raw and intimate intricacies inherent in the highs and lows of the teachers' intercultural dialogic encounters burst out of these narrations. Arising in the universalized global landscape dominated by expectations that the "management of cultural diversity” (Besley \& Peters, 2011, p. 2) depends on dialogue, such intricacies give a glimpse of the reach of the complexity of problems raised in the wider multicultural and intercultural discourse (Council of Europe, 2014). They demonstrate that speech is not only a vulnerable, unpredictable engagement with the moment, but also with its consequences, reaching far beyond the engagement. A tension arises, for example, when speech is problematized to become seen not only as a dialogic, communicative, ostensibly connecting tool, but, on a revelatory level, as an exposure, and possible alienation, of a person's selfhood and identity (Besley, 2007; MacEinri, 1994; Todd, 2004; Wise, 2000). The complications arising in the raw sensitivities of linguistic foreignness have serious implications for dialogic engagements across differences and for the intentions of intercultural educational relationships (Besley \& Peters, 2012; May \& Sleeter, 2010). They encroach on boundaries between sharing allowable, inoffensive or endearing differences, to the point where foreignness becomes so threatening, that speech becomes an impossibility. They rupture the reverence of dialogue as a cure for diversity. A dual focus on the complexity of the dialogic subject and wider context, and on an ethics of care and receptive attention to dialogic engagements as crucial within educational encounters, finds its place in the cracks and crevasses of this rupture.

\section{Bridges and fissures}

When the foreigner teachers feel like the laughing stock of the native teaching team, both they and the other teachers can act only in relation to their own developing subjectivities. Their meanings are contingent, unpredictable and individually transformed and transformative. These foreigner teachers might experience such transformative power as elevating them to new heights, of belonging and recognition, or, equally readily, as the death of their linguistic endeavours, as they collapse into a peaceful release of silence. Bakhtin/Volosinov (1986) argues that an utterance forms a 'bridge' in an encounter, that "[a] word is a bridge thrown between myself and another. If one end of the bridge depends on me, then the other depends upon my addressee. A word is territory shared by both addresser and addressee, by the speaker and his interlocutor" (p. 86). The above insights into teacher foreigners' linguistic experiences suggest a highly complex picture. The uncertainty and incompleteness of the subjects involved in an encounter, 
interminably entwined in their multiple realities, it would seem, may lead also to a fissure, rather than a bridge, as they teeter on the brink of fear and exposure.

The depth of this entangled dialogic interplay compels this analysis to draw on a Bakhtinian/Kristevan theoretical intertextuality. Intersecting elements of unknowability, uncertainty, past and future dialogic implications become further emphasized through such notions as Bakhtin's (1986) super addressee, and Kristeva's psychoanalytic constructions of the subject, and the always present unconscious (Lechte, 1990). Although each is variously considered to exclude either the subject, or the linguistic, dialogic complexity, within this analysis both Bakhtin's and Kristeva's theories crucially support an ethical engagement with dialogue, in the present and with its history/ies, and into the future in individual, often unconscious ways, creating the new life of each engagement (Kristeva, 1986b; Bakhtin, 1986). Following Kristeva, linguistic encounters and developing subjects that are "infinitely in construction" (Kristeva, 2008, p. 2) involve surprise, memories, dreams and fears, that can tear apart, in order to again cohere, in different ways, in the present and in and for the future, adding to and affirming Bakhtinian understandings of the dynamic emergence and transformative life of dialogic encounters. The unknown and difficult implications - the fissures and bridges - of this life reassert the argument for depth, criticality and consideration in educational dialogic relationships.

In relation to dialogic complexity and moral and ethical answerability, it is worth exploring briefly the idea of the subject as constantly in construction (Kristeva, 2000, 2008). Various scholars highlight the un-static nature of the individual subject and the unsuspecting recognition and development of subjectivities (Butler, 2004; Peters \& De Alba, 2012; Stone, 2004, Tesar \& Koro-Ljungberg, 2015), where in the course of the ongoing becoming of a subject, engagements with others can only ever be seen as incomplete representations of their subjectivities. The illustrations of immigrant teacher foreigners demonstrate how the process of becoming carries on during and after an engagement, and how a speaker/author's subjective development has already superseded what was communicated, by the time the reader/listener comes to interpret it. Furthermore, the complexity of the subject in process exceeds that which is consciously knowable even by the author or speaker herself. The very act of a dialogic engagement can therefore be seen as an act of uncertainty, on the basis that what the author or speaker intends to communicate may vary considerably from the nature of the utterance itself, even before it is interpreted by the reader/listener.

The fear of revealing unknown aspects of the self, risking complete exposure, could not only prevent a deep engagement then, but could inhibit any commitment at all to an encounter. This raises not only the idea that recognition of the self by the Other contributes to the formation of the self, but also the validity of silence as a form of representation. By considering text and dialogue as a "mosaic of quotations", enacting and dependent on an interrelated "absorption and transformation of another" (Kristeva, 1986b, p. 37), this insight helps to reposition dialogic encounters as representative of unknown and unpredictably transforming subjectivities. Removed from but representative of subjective realities, voices - and silences -, linguistic, dialogic 
encounters are intricate. This unknowable intricacy calls for a crucial ethical and moral commitment.

In the sense of this uncertainty, working alongside Bakhtin with Kristeva allows a useful exploration of the shift identified by Gurevitch (2000). “A gap opens up” he says in reference to Bakhtin's work, "between the notion of dialogue and its experienced reality" (p. 250). Recognizing the "threat suffering, pain, rage and resentment" that Gurevitch (2000, p. 250) claims is missing in Bakhtin's dialogue, Kristeva's foreigner lens strengthens the call for an ethical focus on tensions, contradictions, displacement and marginalization of the Other in dialogue. At the same time Bakhtin's concern with the integrity of the dialogic social milieu (Gardiner, 1992) reveals that in Bakhtin's thinking too, there is a strong concern for the ethics of ideological discourses, while a concern remains in his fundamental "unresolved ambivalence on questions of ethics and agency" (Erdinast-Vulcan, 1997, p. 251). Calls such as Erdinast-Vulcan’s (1997), for elevating ethics and agency in the contemporary educational milieu nevertheless energise this paper's argument for a heightened focus on an ethics of care for multiplicity and complexity in day-to-day educational dialogic engagements. This relationship can be seen to occur between the indispensable dimensions of dialogic encounters in the symbolic, the semiotic and the contextual social codes of language, whereby the ethics of dialogue lies in the uncertainty and ambivalence that occurs in their interweaving. Ambivalence, for both Bakhtin (1986) and Kristeva (1986b), inserts history and society into the dialogue and dialogue into history, society and into the future, recognising multiple pathways within and surrounding each engagement. A combined Bakhtinian/Kristevan lens strengthens possibilities and insights into the heterogeneity of dialogic engagements with the crisscrossing threads of many divergent, dominant and minority, cultural, social voices as polyphonic, temporal, social and intricately intimate, scary, and personal.

\section{Concluding comments}

An attentive, receptive and reciprocal ethics of care is essential in dialogic relationships with teacher foreigners. In this paper the vulnerability of exposure through dialogic encounters has been exposed as involving a high degree of fear of the unknown. Confronted by this fear and unpredictability, teacher foreigner engagements highlight the complex interrelationship between revelation and meaning, and each of their wider social and political space. This paper has affirmed that the story told is never determined by the author alone, but revealed only through those making sense of the story, filtered through the on-going evolution of culture, time and society. The value of a premature, potentially vulnerable disclosure of an author's still constantly forming selfhood and subjectivity has been highlighted as highly problematic. Further, when engagements become such fearful acts that lead to the absence of life, even to the death, of dialogue, rather than to lively and dialogic interactions, teacher foreigners' silence and our ethical and moral care become crucial ruptures to smooth, expected intercultural educational relations, where dialogic encounters are the expected norm. This paper argues that recognizing and allowing for such ruptures, cracks and fissures is critical in dialogic engagements, as our ethical commitment to educational relationships, settings and realities. 
Bakhtin's many-voiced dialogue underpins this examination of the implications of dialogic encounters in educational relationships, and of engagements with familiarity and risk, in 'themes, composition or style' in dialogue. Bakhtin's claim that "the great dialogue never ends" (Clark \& Holquist, 1984, p. 343), reflects the influences of subjects that are constantly in process on dialogic engagements, as constantly in complex, transforming and transformative construction. Dialogic engagements have been explicated as a complex risky interweaving of utterances arising within the relational and political milieu of author and addressee. They oblige us in a care ethics, as, finally, Todd (2007) reminds us, "each time I come into contact with the situation, where individuals speak to me, they ... command from me an obligation by virtue of the fact that they address me” (pp. 596-597). A dual lens combining Bakhtin's and Kristeva's intertextualities - and even what we might term intra-textuality - has highlighted cracks and fissures within what can otherwise be perceived as safe dialogic encounters. Dialogue itself has been exposed as such an unpredictable and at the same time revelatory act, that engagements become complex expressions of the constantly in process self and society. This paper has argued that receptive, ethical and moral attention is crucial in complex dialogic engagements with teacher foreigners in educational relationships, and that their 'woven fabric' of uncertainties must be carefully contemplated in its intertextual multiplicities, revelations and exposures. Honouring dialogue as an ethical and moral relational act in itself might then avert educational engagements of lifeless dialogue, fearful exposure and silence.

\section{References}

Ahmed, S. (2000). Strange encounters: Embodied others in post-coloniality. London, UK: Routledge.

Allen, G. (2000). Intertextuality. London, UK: Routledge.

Arndt, S. (2012). Foreigners, immigrants, otherness: A philosophical analysis of complications, delights and tensions. Unpublished Masters Thesis. Faculty of Education, School of Critical Studies. The University of Auckland.

Arndt, S. (2013). Ignorance in a knowledge economy: Unknowing the foreigner in the neoliberal condition. In T. A. C. Besley \& M. A. Peters (Eds.), Re-imagining the creative university for the 21st century (pp. 123-133). Rotterdam, Netherlands: Sense Publishers.

Arndt, S. (2014). Shifting realities: Immigrant teacher transitions into early childhood settings in Aotearoa New Zealand. Early Childhood Folio, 18(2), 2832.

Bakhtin, M.M. (1981). The dialogic imagination (C. Emerson \& M. Holquist, Trans. M. Holquist Ed.). Austin, TX: University of Texas Press.

Bakhtin, M.M. (1986). Speech genres and other late essays (V. W. McGee, Trans. C. Emerson \& M. Holquist Eds.). Austin, TX: University of Texas Press. 
Bakhtin, M.M., \& Volosinov, V.N. (1986). Marxism and the philosophy of language (L. Matejka \& I. R. Titunik, Trans.). Cambridge, MA: Harvard University Press. Barthes, R. (1977). Image - music - text (S. Heath, Trans.). London, UK: Fontana. Besley, T.A.C. (2007). Foucault, truth-telling and technologies of the self: Confessional practices of the self and schools. In M. A. Peters \& T. A. C. Besley (Eds.), Why Foucault? New directions in educational research (pp. 55-69). New York, NY: Peter Lang Publishing.

Besley, T.A.C., \& Peters, M.A. (2011). Interculturalism, ethnocentrism and dialogue. Policy Futures in Education, 9(1), 1-12.

Besley, T.A.C., \& Peters, M.A. (2012). Introduction: Interculturalism, education and dialogue. In T. Besley \& M. A. Peters (Eds.), Interculturalism, education and dialogue. New York, NY: Peter Lang Publishing.

Butler, J. (2004). Precarious life: The powers of mourning and violence. London, UK: Verso.

Clark, K., \& Holquist, M. (1984). Mikhail Bakhtin. Cambridge, MA: Harvard University Press.

Codd, J. (2008). Neoliberalism, globalisation and the deprofessionalisation of teachers. In V. Carpenter, J. Jesson, P. Roberts \& M. Stephenson (Eds.), Ngā kaupapa here: Connections and contradictions in education (pp. 14-24). South Melbourne, Australia: Cengage Learning.

Council of Europe. (2014). Intercultural dialogue. Retrieved 5 February, 2014, from http://www.coe.int/t/dg4/intercultural/concept EN.asp

de Vocht, L. (2015). Reconceptualising teacher-child dialogue in early years education as a moral answerability. International Journal of Early Childhood, 47, 317-330. doi: $10.1007 / \mathrm{s} 13158-015-0140-2$

Duhn, I. (2010). 'The centre is my business': Neo-liberal politics, privatisation and discourses of professionalism in New Zealand. Contemporary Issues in Early Childhood, 11(1), 49-60. doi: 10.2304/ciec.2010.11.1.49

Erdinast-Vulcan, D. (1997). Borderlines and contraband: Bakhtin and the question of the subject. Poetics today, 18(2), 251-269.

Gardiner, M. (1992). The dialogics of critique: M.M. Bakhtin \& the theory of ideology. London, UK: Routledge.

Gurevitch, Z. (2000). Plurality in dialogue: A comment on Bakhtin. Sociology, 34(2), 243-263.

Ho, E., Holmes, P., \& Cooper, J. (2004). Review and evaluation of international literature on managing cultural diversity in the classroom. Wellington, New Zealand: Ministry of Education New Zealand.

Kilito, A. (1994). Dog words. In A. Bammer (Ed.), Displacements: Cultural identities in question. Bloomington, IN: Indiana University Press.

Kristeva, J. (1980). Desire in language: A semiotic approach to literature and art (T. Gora, A. Jardine \& L. S. Roudiez, Trans.). New York, NY: Columbia University Press.

Kristeva, J. (1986a). The system and the speaking subject. In T. Moi (Ed.), The Kristeva Reader (pp. 25-33). Oxford, UK: Blackwell Publishers.

Kristeva, J. (1986b). Word, dialogue and novel. In T. Moi (Ed.), The Kristeva Reader (pp. 34-61). Oxford, UK: Blackwell Publishers Ltd. 
Kristeva, J. (1991). Strangers to ourselves. New York, NY: Columbia University Press.

Kristeva, J. (2000). Crisis of the European subject (S. Fairfield, Trans.). New York, NY: Other Press.

Kristeva, J. (2008). "Does European culture exist?". Paper presented at the Dagmar and Václav Havel Foundation VIZE 97 prize, Prague Crossroads. http://www.vize.cz/download/laureat-Julia-Kristeva-en-speech.pdf

Lechte, J. (1990). Julia Kristeva. London, UK: Routledge.

Lesic-Thomas, A. (2005). Behind Bakhtin: Russian formalism and Kristeva's intertextuality. Paragraph, 28 (3), 1-20.

MacEinri, P. (1994). How does it feel? Migrants and the postmodern condition. Chimera 87-94.

May, S., \& Sleeter, C.E. (2010). Critical multiculturalism: Theory and praxis. New York, NY: Routledge.

Mohanty, C.T. (2003). Feminism without borders: Decolonizing theory, practicing solidarity. London, UK: Duke University Press.

Noddings, N. (2012). The language of care ethics. Knowledge Quest, 40(4), 52-56.

Peters, M.A. (2013). Citizenship, human rights and identity: Prospects of a liberal cosmopolitan order. New York, NY: Addleton Academic Publishers.

Peters, M.A., \& De Alba, A. (2012). Introduction. In M. A. Peters \& A. De Alba (Eds.), Subjects in process: Diversity, mobility, and the politics of subjectivity in the 21st century. Boulder, CO: Paradigm Publishers.

Ritchie, J. (2008). Honouring Māori subjectivities within early childhood education in Aotearoa. Contemporary Issues in Early Childhood, 9(3), 202-210.

Ritchie, J., \& Rau, C. (2006). Enacting a whakawhanaungatanga approach in early childhood education. Early Childhood Folio, 10, 16-20.

Stone, L. (2004). Julia Kristeva's 'mystery' of the subject in process. In J. D. Marshall (Ed.), Poststructuralism, philosophy, pedagogy (pp. 119-139). Dordrecht, The Netherlands: Kluwer Academic Publishers.

Tesar, M., \& Koro-Ljungberg, M. (2015). Cute, creepy and sublime unnamed childhood monstrosities. Discourse: Studies in the Cultural Politics of Education, 1-11. doi: 10.1080/01596306.2015.1075708.

Todd, S. (2004). Teaching with ignorance: Questions of social justice, empathy, and responsible community. Interchange, 35(3), 337-352.

Todd, S. (2007). Promoting a just education: Dilemmas of rights, freedom and justice. Educational Philosophy and Theory, 39(6), 592. doi: 10.1111/j.14695812.2007.00310.x

Volosinov, V.N. (1973). Marxism and the philosophy of language (L. Matejka \& I. R. Titunik, Trans.). Cambridge, MA: Harvard University Press.

White, E.J. (2009). A Bakhtinian homecoming. Journal of early childhood research, $7(3)$, 299-323. doi: 10.1177/1476718X09336972

White, E.J. (2015). Bringing dialogism to bear in the early years. International Journal of Early Childhood, 47, 213-216.

Wise, J.M. (2000). Home: Territory and identity. Cultural Studies, 14(2), 295-310. 
